express words as well as the general bent of his argument seemed to point in the opposite direction. Thus at p. $8 \mathrm{r}$ he writes :"Language is a product of association. . . . Language is a product of an active, not of a passive, process; it is the child of will, not of sensation." The statement that language is "the child of will " seems to me practically identical with the assertion that "speech is the deliberate product of a conscious will," because the will here spoken of, being "an active process," is necessarily conscious.-A. H. KEANE.]

\section{Notes on the Mode of Flight of the Albatross}

WHEN watching the albatross one is struck with the fact that the bird gets up to windward without appearing to use his wings to a degree sufficient to account for the same. The sailors are satisfied with the explanation that he beats to windward. The conditions are of course not analogous to those of a ship sailing to windward. If the wind be very light, or if there be a calm, occasional powerful and obvious flapping of the wings occurs. If there is no wind, the birds often settle on the water round the ship. In very heavy weather the birds disappear altogether, probably settling on the water. Except that for breeding they resort to the islands, I believe they frequent the open ocean, where the surface is seldom without more or less swell.

On watching the flight of the albatross, one observes that in order to rise from the water violent and obvious flapping of the wings is necessary, which is continued some time after the wings cease to strike the water. After a start has thus been effected, if there is a fresh breeze, the wings are kept almost motionless. Sometimes the bird goes some distance with the impetus derived from the flapping of the wings at the start, but sooner or later he turns so as to expose the plane surface of his wings full to the force of the wind, rising at the same time some height above the water, and drifts off to leeward, thus soon acquiring the velocity of the wind; then swooping down into the hollow between two swells, he turns his head to windward, and keeping close to the surface of the water, sails along more or less against the wind for a surprising distance ; finally, rising over the crest of a wave comparatively high into the air, and turning with his wings as before, so as to catch the wind to the fullest extent, he again lets himself drift off to leeward.

Thus the manceuvre he performs seems to consist in drifting with the wind in such a way as to attain its velocity very soon, and then turning round so as to make use of this velocity to carcy him in the contrary direction.

Of course if he still remained exposed to the wind which had imparted to him its velocity he would not travel far against it before he came to a standstill, and he would certainly make no progress to windward; but by keeping close to the surface of the water, and as much as possible in the hollows between the waves, he is almost out of the wind; and in this comparatively calm region the impetus derived from the wind will carry him a long distance in exactly the opposite direction to that of the wind itself.

This manouvre appears to be an important factor. No doubt the almost imperceptible movement of the wings may assist, though that this alone is insufficient to account for the progress to windward appears evident from the powerful efforts made with the wings in rising from the water and in calm weather: I have never had an opportunity to observe the albatross flying over land or over level water. If the manœuvre above described be an important factor, the birds then would have to use their wings much as they do in very light winds on the ocean. If very strong winds were blowing, they would have to settle on the land or in the water in order to remain at the locality. ARTHUR W. BATEMAN

\section{A General Theorem in Kinematics}

Prof. Everett (ante, p. 99) has overlooked in the intrcductory paragraphs of Prof. Schell's paper, to which he refers for the original statement of the theorem re-discovered by Prof. Minchin, the acknowledgment : "Der Mittelpunkt der Beschleunigungen und jene beiden Kreise wurden bereits I 853 von BRESSE gefunden." The reference is to the Fournal de l'Ecole Poly" technique, tom. xx., "Mémoire sur un Théorème nouveau concernant les Mouvements Plans, etc." By means of the "two circles" Bresse determines the point $c(J)$ "qui aura une accélération totale nulle" (p. 82), and then by very ingerious applica- tion of kinematic principles deduces those relations to it which any arbitrary point $(P)$ has, as given by Prof. Minchin. Bresse names $c$ "second centre instantané de rotation."

University Hall, December 4

J. J. WALKER

\section{Geometrical Optics}

YOUR correspondent “P. C." (NATURE, vol. xxii. p. 607) asks information concerning a work, in English or French, on geometrical optics, thoroughly explaining the optical construction of telescopes and microscopes. I am not aware of any such publication these last forty years, but deem it possible that it may interest your correspondent to know of the existence of such a work in German by von Littrow, entitled "Dioptrik, oder Anleitung zur Verfertigung der Fernröhre." It was published, I believe, in Vienna about 1838 .

W. G. Logeman

High Burghal School, Haarlem, Holland, November 17

[Littrow's "Dioptrik" was published at Vienna in 1830 in Svo.-ED.]

\section{Ozone}

IF a slip of the prepared paper, used for testing for atmospheric ozone, be carefully moistened on one side with alcohol, using a. clean camel-hair brush, on burning off the spirit and immersing the slip of paper in water the paper changes to a deep purple colour, as deep as No. 8 in Negretti and Zambra's scale of colours for ozone.

Is this due to the development of ozone? as, according to Schönbein, heat destroys ozone.

Leicester, December 5

\section{PLANTS OF MADAGASCAR}

$\mathrm{D}^{\mathrm{U}}$ URING the present year no less than four separate collections of plants have been received at $\mathrm{Kew}$ from Madagascar, including in the aggregate about a thousand species, represented by specimens complete enough to be botanically determinable. As the hills of the interior of the island attain an elevation of 10,000 feet, its range of climate is considerable. We now know not less than two thousand Madagascar flowering-plants, and probably have almost exhausted its ferns, to which the collectors have paid special attention, and which are about 250 in number, so that we may consider ourselves in a position to draw broad general conclusions as to the botany of the island.

Amongst the tropical types there are a considerable number of endemic genera. The lemurs find their parallel in the vegetable kingdom in the Chlanacea, a natural order whose nearest affinities are with Tiliacea, Dipterocarpee, and Ternstromiacee, which is strictly confined to Madagascar, and comprises four genera and about twice as many species, to which the Rev. R. Baron, in these new collections, has added a well-marked novelty in a second species of Leptolona. Altogether there are certainly not less than fifty genera confined to the island, some of them very curious types, as Dicoryphic in Hamamelidece, Ouvirandra in Naiadacea, Asteropeia (placed in the "Genera Plantarum" in Samydacece, but which Mr. Baron's excellent new specimens will most likely have to be removed to Linacea), Macarisia in Rhizophorea, Deidamia and Physena in Passiflorece, Hydrotriche in Scrophulariacece, Canctia, Tánnodia and Spharostylis in Euphorbiacee, Pachnotrophe in Morea, Calantica in Samydacece, and several each in the orders Rubiacea, Melastomacea, and Composite. To these endemic types the new collections add at last three, Kitchingia, a fine new genus of Crassulacee allied to Bryophyllum, with five or six species named after the collector of the first of the four parcels, Rhodocodon, a monotypic genus of gamophyllous Liliacea allied to Hyacinthus, and Micronychia, in Anacardiacea, also monotypic, figured lately in Hooker's Icones. Besides these the tropical flora of the island contains a large proportion : first, of endemic species of genera known elsewhere; second, of species 